\title{
PENENTUAN BATAS DETEKSI METODE (METHOD DETECTION LEVEL) DAN BATAS KUANTIFIKASI (LIMIT OF QUANTITATION) PENGUJIAN SULFIDA DALAM AIR DAN AIR LIMBAH DENGAN BIRU METILEN SECARA SPEKTROFOTOMETRI
}

\author{
Anwar hadi ${ }^{1}$ \\ (Diterima tgl : 1............; Disetujui tgl : ..................)
}

\begin{abstract}
The method detection limit (MDL) is defined as the constituent concentration that, when processed through the complete method, produce a signal with a 99\% probability that is different from blank. The MDL can be achived by experienced analysts operating well-calibrated instruments on a nonroutine basis. However, level of quantitation (LoQ) is the constituent concentration that produces a signal sufficiently greater than the blank that it can be detected within specified levels by good laboratories during routine operating conditions. Determination of MDL for sulfide using methylene blue method with spectrofotometry according APHA 21st edition, 45000-S2-D, 2005 is $0,01 \mathrm{mg} / \mathrm{L}$ and $L o Q$ is $0,02 \mathrm{mg} / \mathrm{L}$. With $\% R S D=10,5 \%$, everage $\% R=95 \%$ and $M D L<$ spike level $<10 M D L=$ $0,01<0,02<0,1$, so the MDL and LoQ is acceptable according to US-EPA requirements.
\end{abstract}

Keywords: Sulfide, Method Detection Level (MDL,) metile blue, and spectrophotometry

\begin{abstract}
ABSTRAK
Batas deteksi metode didefinisikan sebagai konsentrasi analit yang ditentukan sesuai tahapan metode pengujian secara menyeluruh sehingga menghasilkan signal dengan probabilitas $99 \%$ bahwa signal tersebut berbeda dengan blanko. Batas deteksi metode dapat diperoleh ketika dilakukan oleh analis yang kompeten dengan menggunakan peralatan terkalibrasi pada keadaan yang dirancang sedemikian rupa sehingga berbeda dengan kegiatan pengujian rutin. Sedangkan batas kuentifikasi adalah konsentrasi analit yang menghasilkan signal lebih besar dari blanko pada kondisi kegiatan rutin laboratorium. Penentuan MDL untuk sulfide secara biru metilen dengan spektrofotometri sesuai APHA edisi 21 tahun 2005, 4500-S2-D adalah 0,01 mg/L dan LoQ 0,02 mg/L. Dengan \%RSD = 10,5\%, rerata $\% \mathrm{R}=95 \%$ dan $\mathrm{MDL}<$ kadar spike $<10 \mathrm{MDL}=0,01<0,02<0,1$ maka MDL dan LoQ dapat diterima sesuai persyaratan US-EPA.
\end{abstract}

Kata Kunci: Sulfida, batas deteksi metode, biru metilen dan spektrofotometri

\section{PENDAHULUAN}

Untuk mendapatkan validitas data hasil pengujian parameter kualitas lingkungan, maka disamping pengujian dilakukan oleh personil yang kompeten dengan menggunakan peralatan ukur yang telah dikalibrasi dan/ atau dicek serta sumber daya laboratorium yang mendukung, juga penggunaan metode yang valid memegang peranan yang sangat penting. Penggunakan metode yang valid, akan dapat mengetahui tingkat akurasi dan presisi dari suatu data hasil pengujian. Bila laboratorium menggunakan metode standar yang telah dipublikasi dan sudah divalidasi oleh lembaga atau organisasi nasional maupun internasional, maka laboratorium harus melakukan revalidasi atau verifikasi metode tersebut meskipun hanya meliputi aspek-aspek tertentu saja.

Perlu diperhatikan bahwa, setiap laboratorium memiliki kondisi yang berbeda, misalnya sarana akomodasi dan lingkungan pengujian, kompetensi personil, kemampuan peralatan, sehingga kinerja laboratorium yang satu berbeda dengan laboratorium lain dalam 
menerapkan metode standar. Verifikasi metode merupakan proses mendapatkan informasi penting untuk menilai kemampuan sekaligus keterbatasan dari suatu penerapan metode pengujian standar di laboratorium. Perlu diperhatikan bahwa revalidasi selalu merupakan keseimbangan antara kemungkinan biaya, resiko dan teknis. Karena itu, hal-hal yang biasanya menjadi bahan pertimbangan dalam melaksanakan revalidasi metoda, antara lain: keterbatasan biaya, waktu, dan personil; kepentingan laboratorium; kepentingan pelanggan; dan diutamakan untuk pekerjaan yang bersifat rutin.

Salah satu parameter yang harus diuji dalam verifikasi metode adalah penentuan batas deteksi metode (method detection level, MDL). MDL merupakan kemampuan sekaligus keterbatasan laboratorium dalam menerapkan suatu metode pengujian tertentu pada kadar rendah metode tersebut. Penentuan batas deteksi bertujuan untuk menghindari penulisan laporan hasil pengujian tidak terdeteksi (not detectable, ND) yang merupakan informasi tidak informatif. Dalam kajian ini, ruang lingkup penentuan batas deteksi metode pengujian ditetapkan untuk parameter sulfida dalam air dan air limbah dengan biru metilen secara spektrofotometri sesuai SNI 6989.70: 2009. Secara prinsip sulfida bereaksi dengan ferri klorida dan dimetil-p-fenilendiamina membentuk senyawa berwarna biru metilen, kemudian diukur pada panjang gelombang $664 \mathrm{~nm}$ menggunakan spektrofotometer UV$\operatorname{Vis}(1 ; 2)$.

\section{METODOLOGI}

Untuk mendapatkan data MDL yang valid maka persiapan harus sedemikian rupa sehingga kaidah-kaidah penentuan MDL dan batas keberterimaannya dapat memenuhi syarat. Adapun hal-hal yang harus dipertimbangkan antara lain(3):

\section{1) Personil}

Personil yang melakukan penentuan MDL harus memiliki kompetensi berdasarkan pendidikan, pelatihan, serta pengalaman yang sesuai dan/atau keterampilan yang ditunjukkan terkait dengan pengujian parameter sulfida dalam air dan air limbah dengan biru metilen secara spektrofotometri. Sebagai bukti kompetensinya, maka sebelum melakukan penentuan MDL, personil yang bersangkutan harus dievaluasi melalui Analyst Proficiency Test atau Initial Demonstration of Capability for Analyst. Namun hingga saat ini, analyst proficiency test belum merupakan bagian persyaratan dari lembaga sertifikasi personil atau ketentuan ISO/IEC 17025.

\section{2) kondisi akomodasi dan lingkungan pengujian}

Kondisi akomodasi dan lingkungan pengujian harus dapat memenuhi persyaratan berdasarkan SNI 6989.70: 2009. Selama melakukan penentuan MDL, kondisi akomodasi dan lingkungan pengujian harus dipantau dan dikendalikan. Rekaman kondisi akomodasi dan lingkungan pengujian sebagaimana penentuan MDL harus dipelihara.

\section{3) Bahan kimia dan bahan habis pakai}

Bahan kimia yang meliputi antara lain: reagen, pelarut dan bahan habis pakai yang digunakan untuk penentuan MDL harus memiliki kemurnian tinggi (pro analysis) sedangkan akuades yang digunakan untuk penentuan MDL harus air suling yang tidak mengandung sulfida. 


\section{4) Peralatan}

Semua peralatan yang digunakan untuk penentuan MDL yang mempunyai pengaruh yang signifikan pada akurasi atau keabsahan hasil harus dikalibrasi dan/atau dicek sebelum mulai digunakan. Peralatan gelas yang digunakan untuk penentuan MDL harus dikalibrasi atau dapat menggunakan peralatan gelas dengan klasifikasi A sebagaimana dalam
Tabel 1.

Sedangkan peralatan utama dan peralatan pendukung yang digunakan untuk penentuan MDL harus dikalibrasi dan/atau dicek sebelum digunakan untuk menjamin kinerja peralatan. Uji kinerja peralatan pendukung dan peralatan utama dilakukan sesuai instruksi manual dari pabrik pembuat peralatan atau sebagaimana dalam Tabel 2.

Tabel 1. : Klasifikasi peralatan gelas ${ }^{(6)}$

\begin{tabular}{|c|c|c|c|}
\hline \multirow{3}{*}{ Peralatan gelas } & \multirow{2}{*}{ Volume $(\mathrm{mL})$} & \multicolumn{2}{|c|}{ Kesalahan pengukuran $( \pm \mathrm{mL})$} \\
\cline { 2 - 4 } & & Klas A & Klas B \\
\hline \multirow{3}{*}{ Pipet } & 1 & 0,006 & 0,012 \\
\cline { 2 - 4 } & 2 & 0,006 & 0,012 \\
\cline { 2 - 4 } & 5 & 0,01 & 0,02 \\
\cline { 2 - 4 } & 10 & 0,02 & 0,04 \\
\hline \multirow{3}{*}{ Labu Ukur } & 50 & 0,05 & 0,10 \\
\cline { 2 - 4 } & 100 & 0,08 & 0,16 \\
\cline { 2 - 4 } & 500 & 0,20 & 0,40 \\
\cline { 2 - 4 } & 1000 & 0,30 & 0,60 \\
\hline Buret & 50 & 0,05 & 0,10 \\
\hline
\end{tabular}

Sumber : ASTM E288, E542 dan E694 dalam David Harvey, 2000, Modern Analytical Chemistry

Tabel 2. : Uji Kinerja Peralatan Pendukung

\begin{tabular}{|c|c|c|c|c|}
\hline Peralatan & $\begin{array}{l}\text { Bagian yang } \\
\text { dicek }\end{array}$ & Bahan/alat yang digunakan & & Prosedur \\
\hline \multirow{4}{*}{ Timbangan analitik } & $\begin{array}{l}\text { Repeatabilitas, } \\
\text { linearitas dan } \\
\text { akurasi }\end{array}$ & Anak timbangan yang terkalibrasi & \multicolumn{2}{|c|}{$\begin{array}{l}\text { Kalibrasi meliputi daerah } \\
\text { kerja }\end{array}$} \\
\hline & $\begin{array}{c}\text { Level } \\
\text { keseimbangan }\end{array}$ & & \multicolumn{2}{|c|}{$\begin{array}{l}\text { Pastikan level keseimbangan } \\
\text { pada posisi yang benar }\end{array}$} \\
\hline & Titik nol & & \multicolumn{2}{|c|}{$\begin{array}{c}\text { Pastikan timbangan } \\
\text { menunjukan angka nol saat } \\
\text { dihidupkan }\end{array}$} \\
\hline & Kebersihan & & \multicolumn{2}{|c|}{$\begin{array}{l}\text { Pastikan kebersihan } \\
\text { timbangan sebelum dan } \\
\text { setelah melakukan } \\
\text { penimbangan } \\
\end{array}$} \\
\hline \multirow{8}{*}{$\begin{array}{l}\text { UV-Visible } \\
\text { Spectrophotometer } \\
\text { atau Colorimeter }\end{array}$} & $\begin{array}{l}\text { Akurasi } \\
\text { panjang } \\
\text { gelombang }\end{array}$ & Filter holmium dan/atau filter didinium & \multicolumn{2}{|c|}{$\begin{array}{l}\text { Periksa panjang gelombang } \\
\text { daerah } U V \text {-Visible dengan } \\
\text { maksimum deviasi } \pm 1,00 \mathrm{~nm}\end{array}$} \\
\hline & \multirow{5}{*}{$\begin{array}{c}\text { Akurasi } \\
\text { photometric } \\
\text { daerah UV }\end{array}$} & \multirow{5}{*}{$\begin{array}{c}(60 \pm 0,25) \mathrm{mg} \mathrm{K} \mathrm{Kr}_{2} \mathrm{O}_{7} / \mathrm{L} \text { dalam } \\
0,005 \mathrm{M} \mathrm{H}_{2} \mathrm{SO}_{4}\end{array}$} & $\lambda(\mathrm{nm})$ & Absorbansi \\
\hline & & & 235 & $0,748 \pm 0,008$ \\
\hline & & & 257 & $0,865 \pm 0,009$ \\
\hline & & & 313 & $0,292 \pm 0,003$ \\
\hline & & & & $\begin{array}{l}0,640 \pm 0,006 \\
0,688 \pm 0,009\end{array}$ \\
\hline & \multirow{2}{*}{$\begin{array}{c}\text { Akurasi } \\
\text { photometric } \\
\text { daerah Visible }\end{array}$} & \multirow{2}{*}{$20 \mathrm{~g} \mathrm{CuSO}_{4} .5 \mathrm{H}_{2} \mathrm{O} / \mathrm{L}$ dalam $1 \% \mathrm{H}_{2} \mathrm{SO}_{4}$} & 650 & $0,224 \pm 0,0045$ \\
\hline & & & $\begin{array}{l}700 \\
750\end{array}$ & $\begin{array}{c}0,527 \pm 0,0105 \\
0,817 \pm 0,016\end{array}$ \\
\hline
\end{tabular}

Sumber : Maria Csuros, 1995 dan Pedoman KAN No. SR-03 DP.01.17 Januari 2004 
Bila persiapan telah dilakukan maka langkah selanjutnya adalah pembuatan kurva kalibrasi awal (preliminary calibration curve) yang didasarkan pada rentang metode pengujian SNI 6989.70-2009 yaitu 0,02 $\mathrm{mg} \mathrm{S}^{2-} / \mathrm{L}-1,0$ $\mathrm{mg} \mathrm{S}$ 2-/L. Idealnya, 10 deret larutan kerja tanpa blanko digunakan untuk pembuatan kurva kalibrasi awal. Buat kurva kalibrasi yang merupakan hubungan antara kadar larutan kerja dengan respon instrumen (absorbansi) serta tentukan persamaan garis regresinya. Jika koefisien korelasi regreasi linier (r) $<0,995$, maka periksa kondisi alat serta ulangi pengukuran deret kadar larutan kerja hingga diperoleh nilai koefisien $r \geq 0,995(4)$. Jika persamaan regresi linear dalam kurva kalibrasi yang terbentuk telah memenuhi batas keberterimaan secara statistika maka tentukan method slope (b) yang diperoleh dari kemiringan kurva kalibrasi.

Untuk menentuan MDL, maka kadar sulfida 0,02 $\mathrm{mg} \mathrm{S}^{2-} / \mathrm{L}$ ditambahkan ke dalam sampel (laboratory fortified matrix, LFM) yang memiliki kadar sulfida yang sangat-sangat kecil. Sehubungan dengan hal tersebut, maka terhadap matrik tersebut harus dianalisis terlebih dulu dan dipastikan tidak mengandung sulfida. Jika matrik yang tidak mengandung sulfida sulit diperoleh, maka dapat diganti dengan air akuades. Dalam hal ini disebut Laboratory Fortified Blank (LFB)(5).

\section{HASIL DAN PEMBAHASAN}

Method Detection Level adalah kadar analyte yang ditentukan sesuai tahapan metode pengujian secara menyeluruh sehingga menghasilkan signal dengan probabilitas 99\% bahwa signal tersebut berbeda dengan blanko. Nilai MDL dapat dihitung dengan menggunakan rumus:

$\mathrm{MDL}=\mathrm{t}(0.01 ; \mathrm{n}-1) \mathrm{sd}$

Keterangan:

$$
\begin{aligned}
\mathrm{t}(0.01 ; \mathrm{n}-1)= & \text { tabel } \mathrm{t} \text { dengan tingkat } \\
& \text { kepercayaan } 99 \% \text { dan } \\
& \text { tingkat kebebasan } \mathrm{n}-1 \\
\mathrm{sd} \quad & \text { standar deviasi }
\end{aligned}
$$

Minimum pengujian dalam penentuan MDL adalah 7 kali pengulangan dengan minimum 3 hari yang berbeda, karena itu MDL dapat dintayakan dengan:

$\mathrm{MDL}=3,143 \mathrm{sd}$ 
Tabel 3. : Nilai t tabel $($ Student's $-t)$

\begin{tabular}{|c|c|c|c|c|c|c|c|c|}
\hline$d f l p$ & 0,40 & 0,25 & 0,10 & 0,05 & 0,025 & 0,01 & 0,005 & 0,0005 \\
\hline 1 & 0,324920 & 1,000000 & 3,077684 & 6,313752 & 12,70620 & 31,82052 & 63,65674 & 636,6192 \\
\hline 2 & 0,288675 & 0,816497 & 1,885618 & 2,919986 & 4,30265 & 6,96456 & 9,92484 & 31,5991 \\
\hline 3 & 0,276671 & 0,764892 & 1,637744 & 2,353363 & 3,18245 & 4,54070 & 5,84091 & 12,9240 \\
\hline 4 & 0,270722 & 0,740697 & 1,533206 & 2,131847 & 2,77645 & 3,74695 & 4,60409 & 8,6103 \\
\hline 5 & 0,267181 & 0,726687 & 1,475884 & 2,015048 & 2,57058 & 3,36493 & 4,03214 & 6,8688 \\
\hline 6 & 0,264835 & 0,717558 & 1,439756 & 1,943180 & 2,44691 & 3,14267 & 3,70743 & 5,9588 \\
\hline 7 & 0,263167 & 0,711142 & 1,414924 & 1,894579 & 2,36462 & 2,99795 & 3,49948 & 5,4079 \\
\hline 8 & 0,261921 & 0,706387 & 1,396815 & 1,859548 & 2,30600 & 2,89646 & 3,35539 & 5,0413 \\
\hline 9 & 0,260955 & 0,702722 & 1,383029 & 1,833113 & 2,26216 & 2,82144 & 3,24984 & 4,7809 \\
\hline 10 & 0,260185 & 0,699812 & 1,372184 & 1,812461 & 2,22814 & 2,76377 & 3,16927 & 4,5869 \\
\hline 11 & 0,259556 & 0,697445 & 1,363430 & 1,795885 & 2,20099 & 2,71808 & 3,10581 & 4,4370 \\
\hline 12 & 0,259033 & 0,695483 & 1,356217 & 1,782288 & 2,17881 & 2,68100 & 3,05454 & 4,3178 \\
\hline 13 & 0,258591 & 0,693829 & 1,350171 & 1,770933 & 2,16037 & 2,65031 & 3,01228 & 4,2208 \\
\hline 14 & 0,258213 & 0,692417 & 1,345030 & 1,761310 & 2,14479 & 2,62449 & 2,97684 & 4,1405 \\
\hline 15 & 0,257885 & 0,691197 & 1,340606 & 1,753050 & 2,13145 & 2,60248 & 2,94671 & 4,0728 \\
\hline
\end{tabular}

Pengulangan pengujian dilakukan dalam rentang waktu minimal 3 hari bertujuan untuk melihat variabilitas hasil pengujian terhadap waktu serta kondisi akomodasi dan lingkungan yang berbeda. Selain itu hal ini dimaksudkan, bahwa penentuan MDL harus dalam keadaan reprodusibilitas.
Untuk menentukan nilai spike yang dibutuhkan dalam penentuan MDL maka secara teoritis, perkiraan perbandingan hubungan antara IDL : LoD : MDL : LoQ = $1: 2: 4: 10$ yang diilustrasikan sebagaimana dalam Gambar 1 dibawah ini dapat digunakan sebagai pertimbangan.

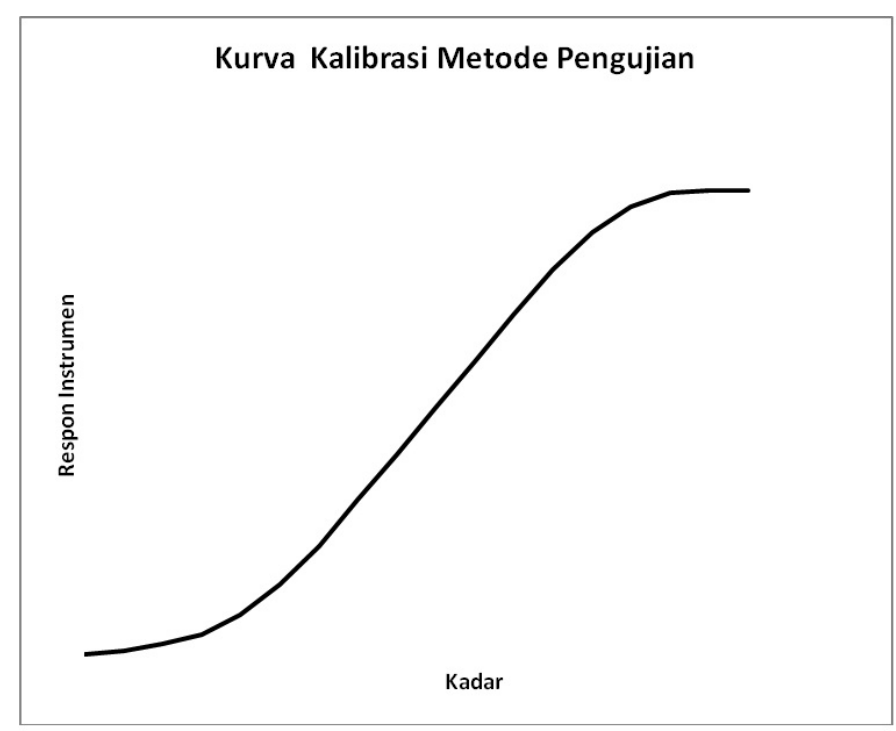

Gambar 3. Windrose Kondisi Udara 
Sehubungan dengan metode pengujian kadar sulfida sesuai SNI 6989.70-2009 mencantumkan batas rendah pengujian (LoQ) yaitu $0,02 \mathrm{~S}^{2-} / \mathrm{L}$ dan dengan mempertimbangkan perbandingan antara MDL : LoQ $=4: 10$, maka informasi ini dapat digunakan untuk menentuan estimasi MDL yaitu:

estimasi $\cdot M D L=\frac{4}{10} \operatorname{Lo} Q=0,4 \operatorname{Lo} Q$

jadi,

estimasi

$$
M D L=0,4(0,02)=0,008 \quad m g / L
$$

Sehubungan dengan MDL merupakan perkiraan batas terendah dari suatu kurva kalibrasi, maka faktor pengali 1 - 5 digunakan sebagai pertimbangan agar kadar analit yang ditambahkan (the spike level) mampu menghasilkan signal. Signal tersebut harus dapat dibedakan dengan background noise dari instrumen namun tidak diperkenankan terlalu tinggi sehingga the signal to noise rasio $(\mathrm{S} / \mathrm{N})$ yang diperoleh dapat diterima secara statistika yaitu $2,5-10$.

sehingga:

0,4 LoQ $(1-5)=(0,4-2) \operatorname{LoQ}$

Dengan demikian kadar spike yang harus ditambahkan berkisar pada rentang kadar

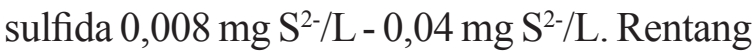
kadar yang diperoleh dapat digunakan sebagai dasar pembuatan larutan kerja sulfida dan dapat ditambahkan ke dalam matrik sebagai laboratory fortified matrix (LFM). Penambahan (spike) larutan kerja ke matrik harus mempertimbangkan bahwa matrik tersebut memiliki kadar sulfida yang sangat-sangat kecil, karena itu terhadap matrik tersebut harus dianalisis terlebih dulu dan dipastikan tidak mengandung sulfida. Dengan mempertimbangkan hal-hal tersebut, maka larutan kerja dengan kadar 0,02 mg $\mathrm{S}^{2-/ L}$ ditambahkan (spike) ke matrik yang memiliki kadar sulfida sangat-sangat kecil dan dianalisis sesuai tahapan SNI 6989.70-2009. Dengan menggunakan kurva kalibrasi awal sebagaimana Tabel 3 dan Gambar 2 maka dapat diperoleh hasil seperti dalam Tabel 4.

Tabel 4: Kurva kalibrasi awal kadar sulfida dalam air

\begin{tabular}{|c|c|c|}
\hline No & Kadar $(\mathrm{mg} / \mathrm{L})$ & Absorbansi \\
\hline 1 & 0,02 & 0,017 \\
\hline 2 & 0,05 & 0,062 \\
\hline 3 & 0,10 & 0,108 \\
\hline 4 & 0,20 & 0,265 \\
\hline 5 & 0,30 & 0,354 \\
\hline 6 & 0,40 & 0,443 \\
\hline 7 & 0,50 & 0,535 \\
\hline 8 & 0,60 & 0,628 \\
\hline 9 & 0,70 & 0,721 \\
\hline 10 & 0,80 & 0,819 \\
\hline 11 & 0,90 & 0,914 \\
\hline 12 & 1,00 & 0,996 \\
\hline \multicolumn{2}{|c|}{ Method slope (b) } & 0,988 \\
\hline \multicolumn{2}{|l|}{ Intercept (a) } & 0,029 \\
\hline \multicolumn{2}{|l|}{ Koefisien korelasi $(r)$} & 0,998 \\
\hline
\end{tabular}

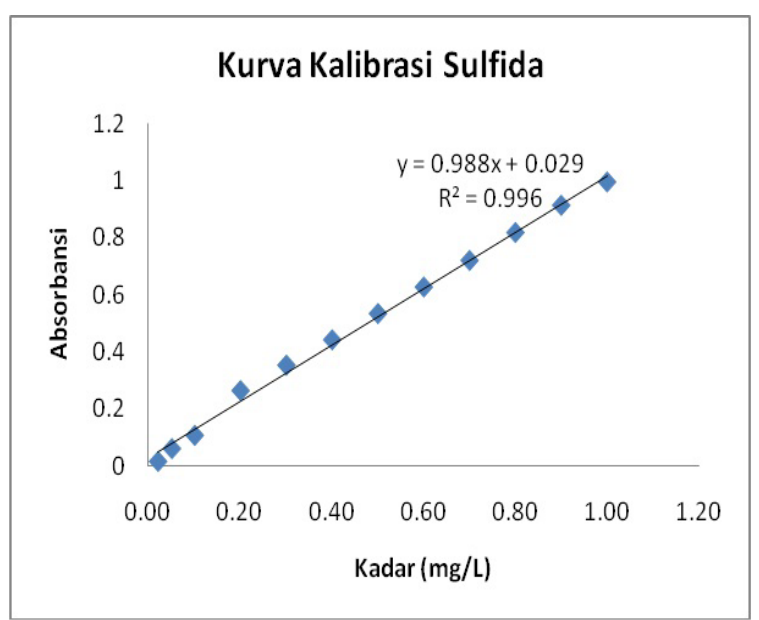

Gambar 2: Kurva kalibrasi sulfida 
Tabel 5: Hasil pengujian sulfida

\begin{tabular}{|c|c|c|c|}
\hline Hari & Absorbansi & Kadar $=\frac{\text { Absorbansi }}{\text { Method Slope }}(\mathrm{mg} / \mathrm{L})$ & $\% R=\frac{\text { Hasil }}{T \arg e t} .100 \%$ \\
\hline Pertama & 0,017 & 0,0172 & 86 \\
\hline Pertama & 0,018 & 0,0183 & 91 \\
\hline Pertama & 0,019 & 0,0193 & 96 \\
\hline Pertama & 0,017 & 0,0172 & 86 \\
\hline Kedua & 0,021 & 0,0213 & 106 \\
\hline Kedua & 0,022 & 0,0223 & 112 \\
\hline Kedua & 0,017 & 0,0172 & 86 \\
\hline Ketiga & 0,021 & 0,0213 & 106 \\
\hline Ketiga & 0,017 & 0,0172 & 86 \\
\hline Ketiga & 0,018 & 0,0183 & 91 \\
\hline & Rerata (x) & 0,0190 & 95 \\
\hline \multicolumn{2}{|c|}{ Standar deviasi (sd) } & 0,0020 & \\
\hline \multicolumn{2}{|c|}{$\%$ RSD $=(\mathrm{sd} / \mathrm{x}) 100 \%$} & 10,5 & \\
\hline \multirow{2}{*}{\multicolumn{2}{|c|}{$\begin{array}{r}\mathrm{S} / \mathrm{N}=\mathrm{x} / \mathrm{sd} \\
\mathrm{MDL}=\mathbf{2 . 8 2 \mathrm { sd }}\end{array}$}} & 9,6 & \\
\hline & & 0,01 & \\
\hline \multicolumn{2}{|r|}{ LoQ $=10$ sd } & 0,02 & \\
\hline
\end{tabular}

Sumber : SNI 6989.70-2009 - Lampiran C

MDL dapat diterima bila data hasil pengulangan pengujian memenuhi batas keberterimaan sebagai berikut $(7 ; 8 ; 9 ; 10 ; 11,12 ; 13 ; 14)$ :

1) simpangan baku relatif yang dinyatakan dalam prosentase (relative standard deviation, \%RSD) yang merupakan perbandingan antara simpangan baku dengan rerata hasil pengulangan pengujian harus memenuhi batasan keberterimaan yang disyaratkan yaitu tidak boleh melebihi $0.67 \mathrm{x}^{2^{1-0,5 \log C}}$ (Tabel 5). Secara matematika dapat dirumuskan sebagai berikut.

$$
\% R S D=\frac{s d}{\bar{x}} \cdot 100 \%<(0,67) 2^{1-0,5 \log C}
$$

Minimal satu blanko metode (method blank) harus dianalisis dalam penentuan MDL sebagai kontrol kontaminasi. Selain itu, blanko metode sangat penting sebagai pengendalian mutu untuk menentukan validitas hasil MDL. Idealnya, nilai kadar blanko mendekati nol atau sangat-sangat kecil dan nilai ini dapat digunakan sebagai pengurang hasil pengujian spike. Bila nilai kadar blanko ditemukan cukup besar maka pengujian dalam penentuan MDL harus diulang. 
Tabel 6: Hasil Perhitungan \%RSD berdasarkan persamaan Horwitz

\begin{tabular}{|c|c|c|c|}
\hline Analit (100\%) & Rasio Analit & Unit & $\begin{array}{c}\text { Batasan maksimum } \\
\% \mathrm{RSD}=0.67 \times 2^{1-0,5 \log C}\end{array}$ \\
\hline 100 & 1 & $100 \%$ & 1,34 \\
\hline 10 & $10^{-1}$ & $10 \%$ & 1,89 \\
\hline 1 & $10^{-2}$ & $1 \%$ & 2,68 \\
\hline 0,1 & $10^{-3}$ & $0,1 \%$ & 3,79 \\
\hline 0,01 & $10^{-4}$ & $100 \mathrm{ppm}$ & 5,36 \\
\hline 0,001 & $10^{-5}$ & $10 \mathrm{ppm}$ & 7,58 \\
\hline 0,0001 & $10^{-6}$ & $1 \mathrm{ppm}$ & 10,72 \\
\hline 0,00001 & $10^{-7}$ & $100 \mathrm{ppb}$ & 15,16 \\
\hline 0,000001 & $10^{-8}$ & $10 \mathrm{ppb}$ & 21,44 \\
\hline 0,0000001 & $10^{-9}$ & $1 \mathrm{ppb}$ & 30,32 \\
\hline
\end{tabular}

Sumber : Guidelines for validation of analytical methods for non-agricultural pesticide active ingredients and product

2) Uji perolehan kembali (recovey test, $\% \mathrm{R}$ ) yang merupakan perbandingan nilai terukur dengan nilai target yang diperoleh dari hasil pengujian harus memenuhi batasan keberterimaan yang disyaratkan tidak boleh melebihi Tabel 5. Secara matematika \%R dapat dirumuskan sebagai berikut.

$\% R=\frac{\text { Nilai } \quad \text { terukur }}{\text { Nilai } \quad t \arg \text { et }} \cdot 100 \%$

Tabel 7: Penentuan batasan awal \%R

\begin{tabular}{|c|c|}
\hline Kadar (unit) & Batasan maksimum \%R \\
\hline $100 \%$ & $98-101$ \\
\hline $10 \%$ & $95-102$ \\
\hline $1 \%$ & $92-105$ \\
\hline $0,1 \%$ & $90-108$ \\
\hline $0,01 \%(100 \mathrm{ppm})$ & $85-110$ \\
\hline $10 \mathrm{ppm}$ & $80-115$ \\
\hline $1 \mathrm{ppm}$ & $75-120$ \\
\hline $10 \mathrm{ppb}$ & $70-125$ \\
\hline
\end{tabular}

Sumber : AOAC Guidelines for Single Laboratory Validation of Chemical Methods for Dietary Supplements and Botanicals
3) The signal to noise ratio $(\mathrm{S} / \mathrm{N})$ yang dinyatakan dalam perbandingan antara rerata hasil pengulangan pengujian dengan simpangan baku harus berkisar antara 2,5-10. S/N merupakan evaluasi kesalahan acak (random error) yang terjadi pada pengujian tertentu dan perkiraan presisi yang diharapkan dari sejumlah pengulangan pengujian.

Bila S/N kurang dari 2,5 maka hal ini menunjukan kesalahan acak yang terjadi dalam pengulangan pengujian terlalu tinggi dan menghasilkan MDL yang tinggi. Dalam hal ini, penambahan analit ke sampel (spike) harus pada kadar yang lebih tinggi agar dapat meningkatkan signal yang ada. Namun sebaliknya, jika $\mathrm{S} / \mathrm{N}$ lebih besar dari 10 maka penambahan kadar analit ke sampel (spike) biasanya terlalu tinggi, karena itu kadar analit yang ditambahkan harus pada kadar yang lebih rendah. Secara matematika S/N dapat 
dirumuskan sebagai berikut:

$$
S / N=\frac{\bar{x}}{s d}=2,5-10
$$

4) Pemilihan kadar spike dalam penentuan MDL harus sedemikian rupa sehingga hasil yang diperoleh memenuhi batas keberterimaan sebagai berikut:

MDL $<$ kadar spike $<10$ MDL

Presisi yang dihasilkan dalam penentuan MDL sangat tergantung dengan kadar spike yang digunakan, karena itu MDL yang dihasilkan harus lebih besar dari 1/10 dari kadar spike. Bila kadar spike melebihi 10 kali MDL maka hal ini berarti bahwa kadar spike terlalu tinggi sehingga penentuan MDL harus diulang dengan menggunakan kadar spike yang lebih rendah. Namun sebaliknya, jika MDL yang dihasilkan lebih besar dari kadar spike yang digunakan maka hal ini berarti bahwa secara statistika sulit dibedakan antara kadar spike dengan blanko dan presisi yang dihasilkan sangat jelek. Karena itu, kadar spike yang terlalu rendah dalam penentuan MDL harus diulang dengan menggunakan kadar spike yang lebih tinggi.
5) Bila secara statistika MDL yang dihasilkan telah memenuhi batas keberterimaan maka MDL tersebut harus dibandingkan dengan nilai baku mutu lingkungan hidup. Jika MDL yang dihasilkan lebih kecil dari nilai baku mutu lingkungan hidup maka laboratorium dapat menggunakan metode tersebut untuk pengujian parameter kualitas lingkungan. Namun, bila MDL yang dihasilkan lebih besar dari nilai baku mutu lingkungan hidup maka laboratorium harus mencari metode pengujian lainnya hingga diperoleh nilai MDL dibawah nilai baku mutu lingkungan hidup.

Batas kuantifikasi (level of quantification, LoQ atau minimum quantitation level, MQL) merupakan kadar analit yang menghasilkan signal lebih besar dari blanko pada kondisi kegiatan rutin laboratorium. LoQ ditentukan sesuai persamaan:

$\mathrm{LoQ}=3,18 \mathrm{MDL}=3,18(3,143 \mathrm{sd})=10 \mathrm{sd} . .(15)$

Dengan menggunakan persamaan (15) tersebut diatas maka nilai LoQ diperoleh:

$\mathrm{LoQ}=10(0,0020)=0,02 \mathrm{mg} / \mathrm{L}$

Dengan membandingkan batas keberterimaan dengan hasil yang diperoleh maka penentuan MDL dapat disimpulkan sebagaimana dalam Tabel 8.

Tabel 8: Batas keberterimaan penentuan MDL dan LoQ sulfida

\begin{tabular}{|c|c|c|}
\hline Persyaratan & Hasil & Kesimpulan \\
\hline 1) $\% \mathrm{RSD} \approx 19,5$ & $10,5 \%$ & Memenuhi \\
\hline 2) $\% \mathrm{R} \approx 75 \%-120 \%$ & $95 \%$ & Memenuhi \\
\hline 3) $\mathrm{S} / \mathrm{N}=2,5-10$ & 9,6 & Memenuhi \\
\hline 4) $\mathrm{MDL}<$ kadar spike & $0,01<0,02$ & Memenuhi \\
\hline 5) Kadar spike $<10 \mathrm{MDL}$ & $0,02<0,1$ & Memenuhi \\
\hline 6) $\mathrm{MDL}<$ baku mutu lingkungan & $0,01<0,3^{*}$ & Memenuhi \\
\hline
\end{tabular}

Catatan: (*) Lampiran Peraturan Menteri Negara Lingkungan Hidup Nomor: 09 Tahun 2007 Tentang Baku Mutu Limbah Bagi Usaha dan/ atau Kegiatan Industri Rayon 


\section{KESIMPULAN}

Penentuan batas deteksi bertujuan untuk menghindari penulisan laporan hasil pengujian tidak terdeteksi (not detectable, ND) yang merupakan informasi tidak informatif. Selain itu, penentuan batas deteksi merupakan kemampuan sekaligus keterbatasan laboratorium dalam menerapkan suatu metode pengujian tertentu pada kadar rendah metode tersebut.

Sehubungan dengan hal tersebut, penentuan batas deteksi metode pengujian parameter sulfida dalam air dan air limbah dengan biru metilen secara spektrofotometri sesuai SNI 6989.70: 2009 diperoleh 0,01 mg/L sedangkan batas kuantifikasi adalah $0,02 \mathrm{mg} / \mathrm{L}$. Bila hal ini dibandingkan dengan rentang metode pengujian yang tercantum dalam SNI 6989.702009 yaitu 0,02 mg S2-/L - 1,0 mg S2-/L maka dapat disimpulkan bahwa penentuan batas deteksi metode (MDL) dan batas kuantifikasi (LoQ) sulfida dalam air dan air limbah dengan biru metilen secara spektrofotometri memenuhi batas keberterimaan.

Bila MDL dan LoQ telah memenuhi batas keberterimaan secara statistika maka batasan ini dapat digunakan sebagai acuan laporan hasil pengujian sebagai berikut:

1) hasil pengujian contoh uji diatas nilai LoQ maka laporan harus mencantumkan nilai estimasi ketidakpastian sehingga laporan hasil pengujian lebih terkuantitatif (laporan $=\mathrm{x} \pm \mathrm{u} 95 \%$ );

2) bila hasil pengujian contoh uji berada diatas MDL namun dibawah LoQ $(\mathrm{MDL}<\mathrm{x}<\mathrm{LoQ})$ maka hasil pengujian dilaporkan tanpa estimasi ketidakpastian (laporan $=\mathrm{x})$;
3) jika hasil contoh uji dibawah MDL maka laboratorium dapat melaporkan $<$ MDL namun laboratorium harus tetap mencantumkan nilai MDL.

\section{DAFTAR PUSTAKA}

1) Standard Methods for the Examination of Water and Wastewater, $21 \mathrm{st}$ edition, 4500-S2-D, 2005, American Public Health Association (APHA), Washington DC USA;

2) Standar Nasional Indonesia, 2009, SNI 6989.70:2009 Air dan air limbah - Bagian 70: Cara uji sulfide dengan biru metilen secara spektrofotometri;

3) International Standards for Organization/International Electrotechnical Commission (ISO/IEC) 17025, 2005, General Requirements for the Competence of Calibration and Testing Laboratories, ISO, Switzerland.

4) Hadi, Anwar, 2009, Pedoman Pengendalian Mutu Internal Pengujian Parameter Kualitas Lingkungan", Asdep Stanteksih KLH.

5) Csuros, Maria, 1994, Environmental Sampling and Analysis for Technicians, Lewis Publishers, USA.

6) Harvey, David, 2000, Modern Analyytical Chemistry, The McGrawHill, USA

7) Anonim, 1996, Analytical Detection Limit Guidance \& Laboratory Guide for Determining Method Detection Limits, Wilconsin Department of Natural Resources, Laboratory Certification Program, 
PUBL-TS-056-96 http://www. dnr. state.wi.us/org/es/science/lc/ OUTREACH/-Publications/LOD\%20 Guidance\%20 Document.pdf (17 September 2010);

8) AOAC Guidelines for Single Laboratory Validation of Chemical Methods for Dietary Supplements and Botanicals, http://www.aoac.org/ dietsupp6/Dietary-Supplement-website/slv_guidelines.pdf(17 September 2010);

9) Validation: An invisible Component of Measurement, http://www.aoac.org/ dietsupp6/Dietary-Supplement-website/HorwitzValid.pdf (17 September 2010);

10) Harmonized Guidelines for Single laboratory Validation of Methods of Analysis (IUPAC Technical Report), Pure Appl. Chem., Vol. 74, No. 5, Pp. 835-855, 2002 http://Www. Iupac.Org/Publications/Pac/2002/ Pdf/7405x0835.Pdf(7 September 2010)

11) Guidelines For Validation of Analytical Methods For Non-
Agricultural Pesticide Active Ingredients And Products http:// www.hse.gov.uk/biocides/copr/pdfs/ validation.pdf (27 September 2010);

12) Ricard Boqué, Alicia Maroto, Jordi Riu and F. Xavier Rius, 2002, Validation of Analytical Methods, Department of Analytical Chemistry and Organic Chemistry University Rovira i Virgili Pl. Imperial Tàrraco, 1, 43005-Tarragona, Spain, Grasas y Aceites 128 Vol. 53. Fasc. 1 (2002), 128-143 http://grasasyaceites. revistas. csic.es/index.php/grasasyaceites/ article/view/295/297(15 September 2010);

13) Douglas Chesher, Evaluating Assay Precision Department of Clinical Biochemistry, Pacific Laboratory Medicine Services, Royal North Shore Hospital, St Leonards NSW 2065, Australia. www.aacb.asn.au/ files/cbr_articles/CBR29_S_pgS23. pdf (15 September 2010);

14) Appendix B to part 136 - definition and procedure for the determination of the method detection limit - revision 1.11 